\title{
Self-Reported Loss of Smell and Taste in SARS-CoV-2 Patients: Primary Care Data to Guide Future Early Detection Strategies
}

$\mathrm{J}$ Gen Intern Med 35(8):2502-4

DOI: $10.1007 / \mathrm{s} 11606-020-05933-9$

(c) Society of General Internal Medicine 2020

\section{INTRODUCTION}

While initial reports did not highlight such symptoms, recent data from several countries suggest that SARS-CoV-2positive inpatients experienced loss of smell and/or taste. ${ }^{1,2}$ In a retrospective web-based study of outpatients who had attended one of three emerging diseases center in France, the combination of hyposmia and hypogeusia had moderate sensitivity $(42 \%)$ and high specificity $(95 \%)$ for the identification of SARS-CoV-2-positive patients. ${ }^{2}$ While loss of smell or taste could be a key symptom to guide early identification of new cases in primary care, the extent to which participants in this study were representative of primary care patients is unclear. To address this limitation, we conducted a study involving primary care patients in France.

\section{METHODS}

This preliminary cross-sectional study was conducted between March 24, 2020, and April 14, 2020, in two clinical laboratories in Lyon (France) to which general practitioners (GPs) refer patients with a suspicion of COVID-19 for a nasopharyngeal smear (RT-PCR).

Before undergoing the test, the patients responded to a preformatted questionnaire about their symptoms, built on previous literature ${ }^{3,4}$ and expert opinion. Data were analyzed using Stata 15, adjusting for clustering within the two laboratories. We examined the univariate and multivariate association between smell and/or taste disorders and a positive SARS-CoV2 test, adjusting for all the other symptoms frequently reported by the patients. We also examined the performance of these smell and taste symptoms in predicting a SARS-CoV-2positive test.

Benoit Tudrej and Paul Sebo are joint first authors.

Received April 27, 2020

Accepted May 18, 2020

Published online June 9, 2020

\section{RESULTS}

A total of 816 consecutively recruited patients were included in the analysis; $532(65 \%)$ were women. The median age was 45 (interquartile range, 28; min-max, 4-92); 302 (37\%) were healthcare professionals. Cough and dry throat were the most frequently reported symptoms (Table 1). Patients who tested positive for SARS-CoV-2 $(n=198(24 \%))$ reported loss of smell or taste significantly more often than patients who tested negative (Table 2). Smell or taste disorders were significantly associated with positive RT-PCR with an adjusted OR $=6.3$ (95\% CI, 5.2-7.5) in this primary care population with a high pre-test probability of COVID-19.

\section{DISCUSSION}

The tropism of SARS-CoV-2 for the nerves of the ear, nose, and throat system ${ }^{5}$ may explain the relatively high proportion of SARS-CoV-2 patients suffering from smell and taste disorders, compared with patients suffering from upper respiratory tract infections with other viruses.

In this epidemic context, a simple clinical screening tool could be very efficient. Smell and taste disorders seem to be very specific to SARS-CoV-2 infection. This is a key finding to inform triage strategies and early isolation of new clusters of infection through primary care. The high specificity of these symptoms means GPs could rely on them to affirm a diagnosis of COVID-19, referring only patients with low pre-test probability (i.e., with non-specific symptoms) to RT-PCR

Table 1 Proportion of Symptoms Reported by Patients $(N=816)$

\begin{tabular}{ll}
\hline \hline Symptoms & $\boldsymbol{N ( \% )}$ \\
\hline Anosmia or hyposmia & $156(19.1)$ \\
Ageusia or hypogeusia & $188(23.0)$ \\
Fever* & $366(44.9)$ \\
Asthenia & $115(14.1)$ \\
Headache* & $359(44.1)$ \\
Cough & $450(55.2)$ \\
Dyspnea & $143(17.5)$ \\
Chest pain* & $164(20.1)$ \\
Myalgia & $166(20.3)$ \\
Diarrhea* & $174(21.4)$ \\
Dry nose* & $173(21.2)$ \\
Stuffy nose* & $211(25.9)$ \\
Dry throat* & $384(47.1)$ \\
Sore throat & $54(6.6)$ \\
\hline
\end{tabular}

*Data missing for 1 patient 
Table 2 Association Between Smell and/or Taste Disorders, and Positivity of the SARS-CoV-2 RT-PCR Test

\begin{tabular}{|c|c|c|c|c|c|c|c|c|c|c|}
\hline Symptoms & $\begin{array}{l}\text { Overall } \\
(N= \\
816), n \\
(\%)\end{array}$ & $\begin{array}{l}\text { Patients } \\
\text { with a } \\
\text { positive } \\
\text { test }(N= \\
198), n \\
(\%)\end{array}$ & $\begin{array}{l}\text { Patients } \\
\text { with a } \\
\text { negative } \\
\text { test }(N= \\
618), n(\%)\end{array}$ & $\begin{array}{l}\text { Crude } \\
\text { OR } \\
(95 \% \\
\text { CI) }\end{array}$ & $\begin{array}{l}p \\
\text { value }^{1}\end{array}$ & $\begin{array}{l}\text { Adjusted } \\
\text { OR (95\% } \\
\text { CI) }\end{array}$ & $\begin{array}{l}\text { Adjusted } \\
p \text { value }^{2}\end{array}$ & $\begin{array}{l}\text { Sensitivity } \\
(\%)\end{array}$ & $\begin{array}{l}\text { Specificity } \\
(\%)\end{array}$ & $\begin{array}{l}\text { ROC } \\
\text { area } \\
(95 \% \\
\text { CI })\end{array}$ \\
\hline $\begin{array}{l}\text { Smell } \\
\text { disorder }\end{array}$ & $\begin{array}{l}156 \\
(19.1)\end{array}$ & 82 (41.4) & $74(12.0)$ & $\begin{array}{l}5.2(4.3- \\
6.3)\end{array}$ & $\begin{array}{l}< \\
0.001\end{array}$ & $\begin{array}{l}6.3(5.8- \\
6.9)\end{array}$ & $<0.001$ & 41.4 & 88.0 & $\begin{array}{l}0.65 \\
(0.61- \\
0.68)\end{array}$ \\
\hline $\begin{array}{l}\text { Taste } \\
\text { disorder }{ }^{4}\end{array}$ & $\begin{array}{l}188 \\
(23.0)\end{array}$ & $92(46.5)$ & $96(15.5)$ & $\begin{array}{l}4.7 \\
(3.4- \\
6.6)\end{array}$ & $\begin{array}{l}< \\
0.001\end{array}$ & $\begin{array}{l}4.9(3.2- \\
7.5)\end{array}$ & $<0.001$ & 46.5 & 84.5 & $\begin{array}{l}0.66 \\
(0.62- \\
0.69)\end{array}$ \\
\hline $\begin{array}{l}\text { Smell and } \\
\text { taste } \\
\text { disorder }\end{array}$ & $\begin{array}{l}102 \\
(12.5)\end{array}$ & $58(29.3)$ & $44(7.1)$ & $\begin{array}{l}5.4 \\
(2.9- \\
10.1)\end{array}$ & $\begin{array}{l}< \\
0.001\end{array}$ & $\begin{array}{l}5.9(3.2- \\
11.1)\end{array}$ & $<0.001$ & 29.3 & 92.9 & $\begin{array}{l}0.61 \\
(0.58- \\
0.64)\end{array}$ \\
\hline $\begin{array}{l}\text { Smell } \text { or } \\
\text { taste } \\
\text { disorder }\end{array}$ & $\begin{array}{l}242 \\
(29.7)\end{array}$ & $116(58.6)$ & $126(20.4)$ & $\begin{array}{l}5.5 \\
(4.6- \\
6.7)\end{array}$ & $\begin{array}{l}< \\
0.001\end{array}$ & $\begin{array}{l}6.3(5.2- \\
7.5)\end{array}$ & $<0.001$ & 58.6 & 79.6 & $\begin{array}{l}0.69 \\
(0.65- \\
0.73)\end{array}$ \\
\hline
\end{tabular}

${ }^{1}$ Univariate logistic regression (adjusted for clustering within labs)

${ }^{2}$ Multivariate logistic regression (adjusted for clustering within labs, gender, age group, and patient reporting of fever, asthenia, headache, cough, dyspnea, chest pain, myalgia, diarrhea, dry nose, stuffy nose, dry throat, sore throat)

${ }^{3}$ Anosmia or hyposmia

${ }^{4}$ Ageusia or hypogeusia

screening. This could be a strategy to consider in lower resource settings, when RT-PCR testing is not widely available, or lack of protective gear would lead to excessive risk of contamination for the caregiver performing the test.

Our study was initiated after the first media reports of a possible link between anosmia and COVID-19. This may have prompted patients to over-report these symptoms, thus affecting their prevalence in our sample. Since patients were asked about the symptoms before receiving the results of their test, this limits the repercussions of this potential reporting bias on our measures of association.

Future studies should explore the diagnostic performance of various combinations of symptoms (i.e., anosmia and ageusia, anosmia without rhinitis, anosmia with nasal dryness...) to increase the specificity of the clinical picture. In accordance with Wynants et al.'s recommendations, ${ }^{6}$ these studies should be performed with a representative dataset (i.e., primary carebased sample), an adequate description of the study population and external validation of the diagnostic tool.

In conclusion, our study shows that smell and taste disorders are common in primary care patients with SARS-CoV-2 infection. These symptoms might represent the first step to build a relatively simple clinical screening tool to use in primary care in an epidemic context. Once confinement measures are lifted, our data could further inform triage and early identification of new clusters of cases through primary care.

Acknowledgments: We thank all patients who accepted to participate in this study. We also thank Rémy Boussageon, Maud Laprée, Edith Corbineau, Jean Pascal Fournier, Cerballiance Part-Dieu and Etats-unis laboratories' teams, the Villon microbiology platform, Amir Moussa for their assistance, and the Maisonneuve family for their support.

Benoit Tudrej, $\mathrm{MD}, \mathrm{Ph} \mathrm{D}^{1,2}$

Paul Sebo, MD, $\mathrm{MSc}^{3}$

Julie Lourdaux, $M D^{4}$
Clara Cuzin ${ }^{1}$

Martin Floquet ${ }^{1}$

Dagmar M. Haller, $\mathrm{MD}, \mathrm{Ph} \mathrm{D}^{3}$

Hubert Maisonneuve, MD, M.Ed $d^{1,2,3}$

${ }^{1}$ University College of General Medicine, University Claude Bernard Lyon 1,

Lyon, France

${ }^{2}$ Mermoz Primary Health Centre,

99 Avenue Jean Mermoz, 69008 Lyon, France

${ }^{3}$ Primary Care Unit, Faculty of Medicine, University of Geneva,

Geneva, Switzerland

${ }^{4}$ Cerballiance Rhône-Alpes Laboratory,

Lyon, France

Corresponding Author: Benoit Tudrej, MD, PhD; Mermoz Primary Health Centre, 99 Avenue Jean Mermoz, 69008 Lyon, France (e-mail:dr.tudrej@gmail.com).

Author Contributions Benoit Tudrej (BT), Hubert Maisonneuve (HM), and Julie Lourdaux (JL) conceptualized and designed the study. Clara Cuzin (CC), Martin Floquet (MF), HM, and JL designed and conducted the data collection. Paul Sebo (PS) and Dagmar M. Haller (DH) performed the data analysis. PS, DH, HM, and BT contributed to the interpretation of the data. PS, DH, HM, and BT wrote the first draft of the manuscript, and all authors approved the final version for submission.

\section{Compliance with Ethical Standards:}

Consent: Before responding to the questionnaire, all patients provided oral consent for their anonymous data to be used for research purposes.

Conflict of Interest: The authors declare that they do not have a conflict of interest.

\section{REFERENCES}

1. Giacomelli A, Pezzati L, Conti F, et al. Self-reported olfactory and taste disorders in SARS-CoV-2 patients: a cross-sectional study. Clin Infect Dis Off Publ Infect Dis Soc Am. 2020. 
2. Bénézit F, Le Turnier $\mathbf{P}$, Declerck $\mathbf{C}$, et al. Utility of hyposmia and hypogeusia for the diagnosis of COVID-19. Lancet Infect Dis. 2020.

3. Guan W-J, Ni Z-Y, Hu Y, et al. Clinical Characteristics of Coronavirus Disease 2019 in China. N Engl J Med. 2020.

4. Wang D, Hu B, Hu C, et al. Clinical Characteristics of 138 Hospitalized Patients With 2019 Novel Coronavirus-Infected Pneumonia in Wuhan, China. JAMA. 2020.

5. Netland J, Meyerholz DK, Moore S, Cassell M, Perlman S. Severe acute respiratory syndrome coronavirus infection causes neuronal death in the absence of encephalitis in mice transgenic for human ACE2. J Virol. 2008; 15:7264-75

6. Wynants L, Van Calster B, Bonten MMJ, et al. Prediction models for diagnosis and prognosis of covid-19 infection: systematic review and critical appraisal. BMJ. 2020;07;369:m1328.

Publisher's Note: Springer Nature remains neutral with regard to jurisdictional claims in published maps and institutional affiliations. 